\title{
Characteristics and field relation of Ulleri Augen Gneiss to country rocks in the Lesser Himalaya: A case study from Syaprubesi-Chhyamthali area, central Nepal
}

\author{
*Jharendra K. C. ${ }^{1}$ and Kabi Raj Paudyal ${ }^{2}$ \\ ${ }^{1}$ Upper Tamakoshi Hydroelectric Project Limited (UTKHPL), Lamabagar Dolakha, Nepal \\ ${ }^{2}$ Central Department of Geology, Tribhuvan University, Kirtipur, Kathmandu, Nepal \\ *Corresponding author: jharendrakc03@gmail.com
}

\begin{abstract}
The distribution of Ulleri Augen Gneiss and its origin in the Lesser Nepal Himalaya adjacent to the Main Central Thrust zone is still a debate among the geo-scientists. Geological mapping was carried out along the Syaprubesi-Chhyamthali area of central Nepal with the aim to study the field relation, distribution, deformation and metamorphism of the Ulleri Augen Gneiss. During mapping, close traverses were set to observe the field relation and a number of systematic samples were collected for analysis of composition and texture. Some preliminary findings were obtained related to its geological position and distribution. This gneiss is hosted within the Kuncha Formation, the oldest unit of the Nawakot Group in the Lesser Himalaya. It has been evolved within this unit as a tabular form in some places and lenses in other places. It shows both concordant (i.e., sill type) and discordant (i.e., dike type) relationship with the host rock. It is characterized by augen-shaped porphyroblasts of K-feldspar and S-C mylonitic texture showing top to the SW sense of shear. The S-C structures and lineated textures shown by the minerals are associated with the shearing caused by the movement along the MCT during the syn-MCT metamorphic deformation. It is characterized in different types of lithologies such as augen gneiss, banded gneiss and two-mica gneiss. An attempt is made to explain the petrological characteristics and field relation of the Ulleri Augen Gneiss with the host rocks along with structural aspects. Based on the field relation and texture analysis, the evolution of the protolith of this Ulleri Augun Gneiss can be interpreted as a multi-story emplacement within the host rocks during and immediately after the sedimentation.
\end{abstract}

Keywords: Ulleri Augen Gneiss, Field relation, Metamorphism, Lesser Himalaya, Central Nepal

Paper Received: 23 Dec 2018

Paper Accepted: 10 Apr 2019

\section{INTRODUCTION}

Nepal Himalaya extending from the Mahakali River in the west to the Mechi River in the east occupies the central part of the Himalayan ranges and represents the typical unit showing the entire regional structure as described by Gansser in 1964. The Nepal Himalaya is divided longitudinally into four tectonic zones known as the Sub-Himalaya, the Lesser Himalaya, the Higher Himalaya and the Tibetan-Tethys Himalaya, from the south to the north, respectively. These tectonic zones are separated by four major faults; i.e. the Himalayan Frontal Thrust (HFT), the Main Boundary Thrust (MBT), the Main Central Thrust (MCT) and the South Tibetan Detachment System (STDS) from south to the north, respectively. The Lesser Himalaya lies in between the Higher Himalaya and the Sub-Himalaya separated by the MCT in the north and the MBT in the south. The Ulleri Augen Gneiss is exposed within the schist, phyllite and metasandstone of the Kuncha Formation of the Lesser Himalaya. The gneiss forms an almost continuous horizon of very variable thickness reaching up to $1500 \mathrm{~m}$ in the region of the Ulleri, central-west Nepal studied by Le Fort and $\mathrm{Pe}^{\wedge}$ cher (1974), Le Fort (1975a and b), Pe^cher and Le Fort (1977), Pe`cher (1978), Arita (1983), Tater et al. (1983), and Colchen et al. (1986).
In the Darondi valley and the Ankhu Khola region, south of the Ganesh Himal, central Nepal other lenticular horizons of the Ulleri Augen Gneiss have been mapped. They lie at different levels within the alteration of schists and greywackes of the Kuncha Formation (Pe^cher, 1978; Colchen et al., 1986). Augen gneisses approaching the MCT are found in the same position and also belong to the upper Midland Group (Rai, 1998); Rai et al., 2017) in the ast of Kathmandu in the lower Sindhu Khola, the north of Kathmandu at Gairigaon along the Phalangu Khola, and the Syabrubensi village at the confluence of the Langtang Khola and the Bhotekoshi River. In some places, the succession represents an inverted lithostratigraphic sequence near to the MCT zone. The Lesser Himalayan rocks along with the gneiss unit in thr Syabrubesi area close to the MCT shows the effect of the poly-phase metamorphism (Rai et al., 2017). The Ulleri Augen Gneiss crops out mainly on the northern limb of the Kuncha-Gorkha anticlinorium of the Midland Group (Pe^cher, 1978; Colchen et al., 1980 and 1986) and Likhu Khola anticline (Rai, 1998) in central Nepal. The Lesser Himalayan gneiss occurs at various stratigraphic levels and hence cannot be attributed to the volcano-sedimentary origin for all of them (Sto“cklin, 1980). Le Fort and Rai (1999) obtained an age of $1.74 \mathrm{Ga}$ by dating $\mathrm{Rb}-\mathrm{Sr}$ isotopes for the Ulleri Augen Gneiss 


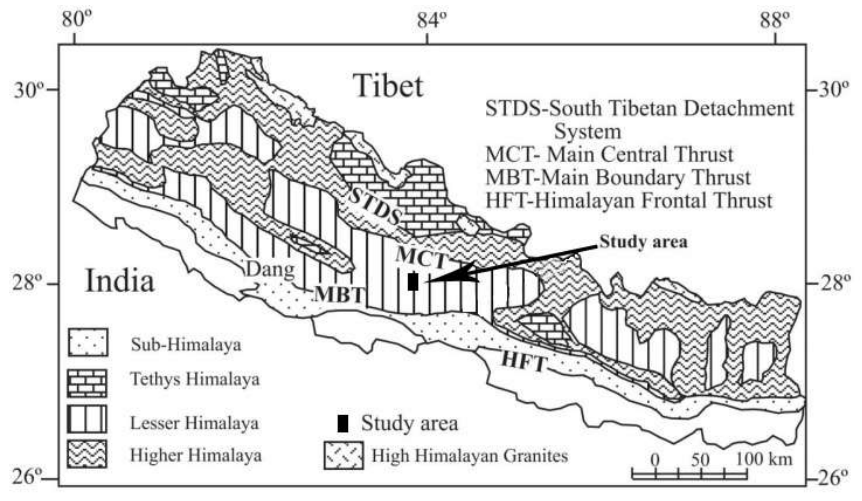

Fig. 1: Geological map of Nepal (Upreti and Le Fort, 1999)

of west Nepal. Parrish and Hodges (1996), Celerier et al. (2009), Kohn et al. (2010), and Martin et al. (2011) found the Precambrian depositional age of the Kuncha Formation which was similar to the magmatic age of the Ulleri Augen Gneiss. This gneiss is dated as $1878 \pm 11 \mathrm{Ma}$ (Khon et al., 2010).

It is granitic augen gneiss consisting of mineral assemblages of quartz, orthoclase, plagioclase, muscovite and biotite. The origin, characteristics and distribution of the gneiss in the Lesser Himalaya has significant role in interpreting tectonic, structural and geomorphological setting of the Himalaya. However, different names have been given in different locality.

The study area lies in the political junction of Dhading, Rasuwa and Nuwakot districts of central Nepal, i.e. from Syaprubesi in the east to the Chhyamthali area in the west. The study area covers nearly $300 \mathrm{sq}$. km of topo-sheet No. 288513. The area is located in between latitudes 280000 to 280700 and longitudes 850000 to 851500 (Fig. 1).

The major objectives of this research is to assess the relationship of the Ulleri Augen Gneiss with the host rocks (i.e. concordant and discordant) along with the study of stratigraphy and tectonic setting of the Ulleri Augen Gneiss. Finally, an attempt was made to correlate the Ulleri Augen Gneiss distributed at its adjacent area in the Lesser Himalaya, central Nepal. There are many geological researches on the augen gneiss succession in central Nepal in the past; however, the present study has focused on the characteristics, tectonic setting and field relation of the augen gneiss with country rocks.

\section{METHODOLOGY}

Reviewing of topographical maps, geological maps, aerial photographs, various articles and journals were made in desk to conduct field work, data collection, sampling, delineating different formations. Mapping the Ulleri Augen Gneiss at $1: 25,000$ scale was made in different parts of the study area to assess the lithological succession and establish the stratigraphy and tectonics to establish the relationships of the gneiss with the host rocks in terms of deformation and metamorphism. Likewise, the relationship (concordant/discordant) between the host rock and intrusion of granitic gneissic bodies, impact and other mineralogical association was noted. Laboratory works were done to accesses the composition and texture of deformation features by under a polarizing microscope.

\section{GEOLOGICAL SETTING}

The study area extending from Syaprubesi in the east to the Chhyamthali area in the west belongs to the Kuncha Formation, the oldest unit of the Nawakot Group (Stöcklin, 1980) (Fig. 2). The Ulleri Augen Gneiss is another major lithological unit exposed within the succession of the Kuncha Formation. The study area is tectonically active showing the small to large scale thrust and shear zones exhibiting the relationships between evolution of the gneiss and its host rocks. Local scale anticline (Kintan anticline) and syncline are the structural features observed in the Kintan Khola section and at the right side of the Kintan-Gumbun road section ().

Litho-stratigraphically, the rocks of the region was mapped under the Kuncha Formation whereas the Ulleri Augen Gneiss was mapped as a member within the Kuncha Formation.

\section{Kuncha Formation}

This formation consists of mainly chlorite-biotite grade grey phyllite/schist, interlayered with fine-grained metasandstone/quartzite and green metabasics (amphibolites). The metasandstone is monotonous, thickly bedded, mediumgrained, grey interparting with highly deformed phyllite. The rock type consisting of thin to thickly bedded, highly compact greenish grey, highly weathered and brownish grey metasandstone is well exposed around Karkigaon near Karkale, Kaule to Salme. Phyllite, another important rock type of the Kuncha Formation, is well exposed around Dhaibun-Satdobate area, however, most of the lower section of the Kuncha Formation exhibits soapy gritty phyllite with variable composition, color and thickness. The phyllite/schist contains mineral assemblage of quartz, plagioclase, biotite, muscovite, sericite, chlorite, \pm chloritoid, \pm garnet (Rai et al., 2008). Zircon grains in the Kuncha Formation at theSyabru Besi area have inherited $\mathrm{U}-\mathrm{Pb}$ ages of 1.8-2.6 Ga (Parrish and Hodges, 1996).

\section{Ulleri Augen Gneiss}

The Ulleri Augen (Figs 2, 3a and 3b) is inter-bedded with the host rocks such as metasandstone and phyllite. From structural and textural point of view, various types of this gneiss like banded gneiss, mica gneiss and augen gneiss were observed in the field. The distribution of gneiss is not continuous rather there are several discrete pockets of the gneiss in patches form (Fig. 2). Likewise, emplacement of the granitic intrusion shows both concordant and discordant relationships with host rocks. It extends from Garsyon in the north-west to Khodku-Siruchet in the south eastern part. These are distributed as patch forms in Bhalche, Salme, Kuri and Gorkan areas whereas they are continuous in the Chhyamthali and the Kodku-Siruchet areas. The major mineralogical assemblages of this gneiss are quartz, 


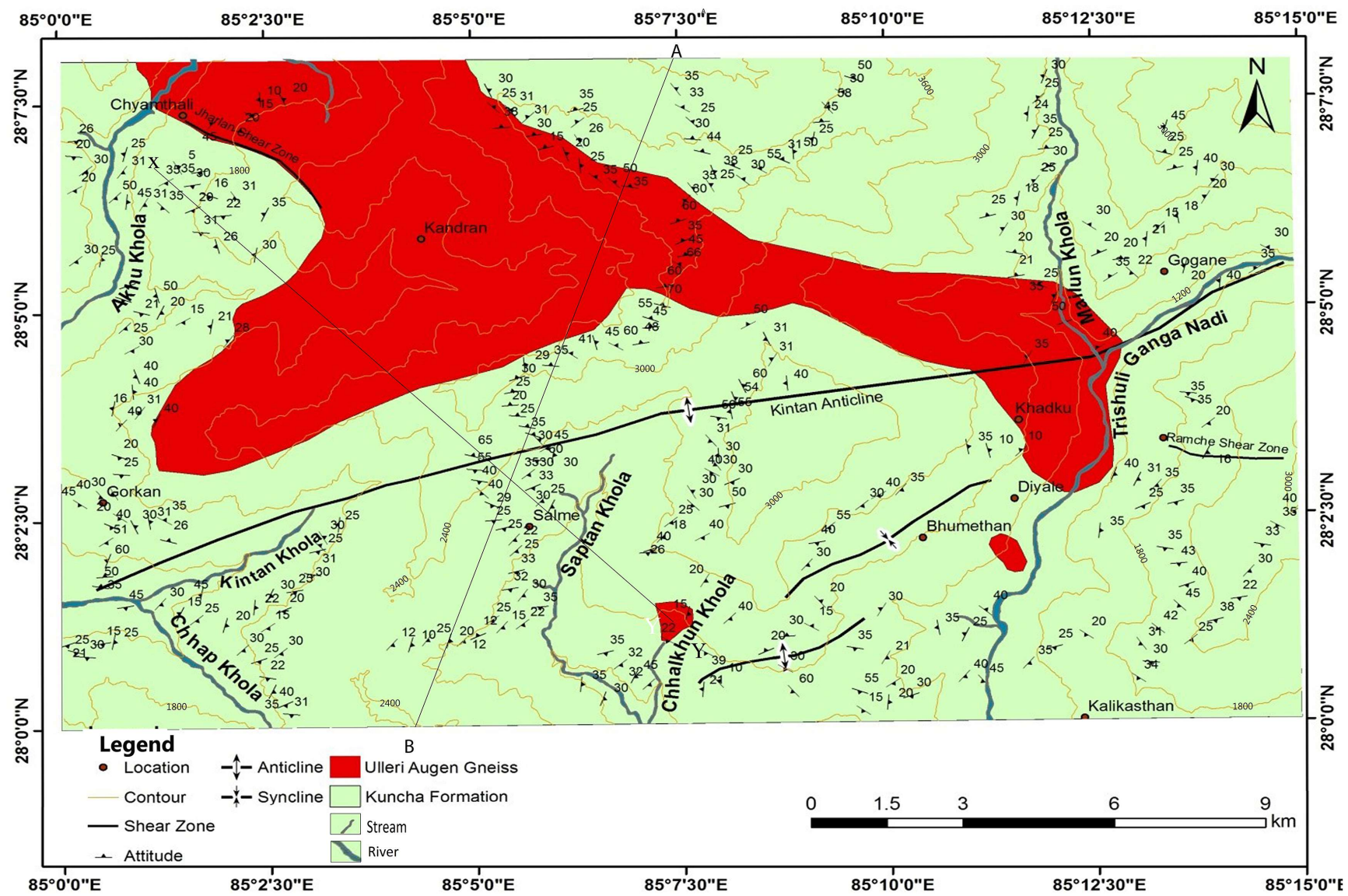

\section{Fig. 2: Geological map of the study area}

plagioclase, biotite and muscovite. The well-developed augen shaped gneiss is observed along the Kintan-Gumbun road section.

\section{Field relation with country rocks}

The contact between the augen gneiss and metasedimentary succession is found to be transitional in some places and sharp in other places within the study area. In the KhodkuSiruchet and the Bhalche areas, the Ulleri Augen Gneiss is interlayered with monotonous succession of brownish grey, mediumbedded metasandstone (Fig. 4). In this section, the intrusion has affected the country rocks. Along the Chhalkhun Khola near the Bhalche area, the Ulleri Augen Gneiss is well foliated with the thin bedded, brownish-grey phyllite (Fig. 5). Similarly, in the Kimtan-Gumbun area, the gneiss is inter-layered with the metasandstone and phyllite (Fig. 6). However, at the Jharlang area the lithological contact between the gneiss and host rock is represented by a shear zone which is mapped as the Jharlang shear zone in the present work.

In the study area, the granitic emplacement shows concordant relationship with the country rock in most of the places except in few places and outcrops. The foliation of augen gneiss is parallel to sub-parallel with the host succession. Such relation can be seen both in field and under the thin sections.

\section{Morphology}

Morphologically, the Ulleri Augen Gneiss possesses a huge mass of granitic emplacement at the upper part of the Kuncha Formation. The shape and size of the gneiss is not uniform throughout the region. It has multistoreyed blocks of the gneiss in some places whereas it also possesses interlayering and inter-fingering exposure in others of the study area.

\section{Distribution}

The distribution of the gneiss is not continuous throughout the study area. There are several discrete pocket of gneiss in patches form along Simle-Diyale foot trail. Similarly, such discrete bodies of gneiss were observed along the foot trail downward from the Ghran to the Trishuli Ganga Nadi. Additionally, the major distribution of the gneiss was observed along the Kintan-Gumbun road section (Fig. 7) where the augen gneissic texture was clearly noted with the transitional contacts with thin bedded metasandstone and phyllite. Similarly, the largest distribution of the gneiss was reported in JharlanChhapthali area. Furthermore, right bank of the Gasali Khola near the Sanyun-Darkha area consists predominantly of the Ulleri Augen Gneiss. The coarse-grained minerals were observed around the central part, whereas the fine-grained minerals were observed in the exocontacts. Near the core of the augen gneiss, 
(a)

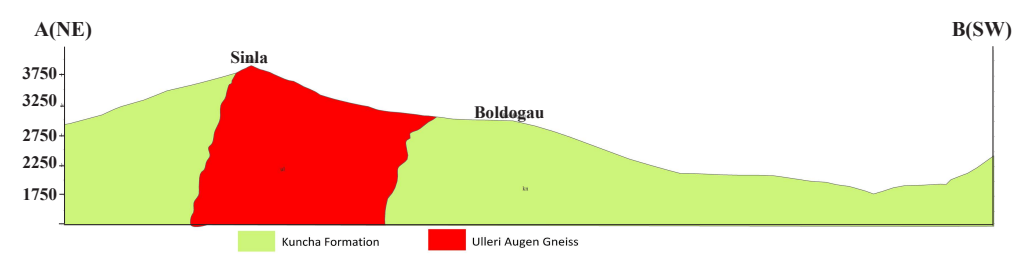

(b)

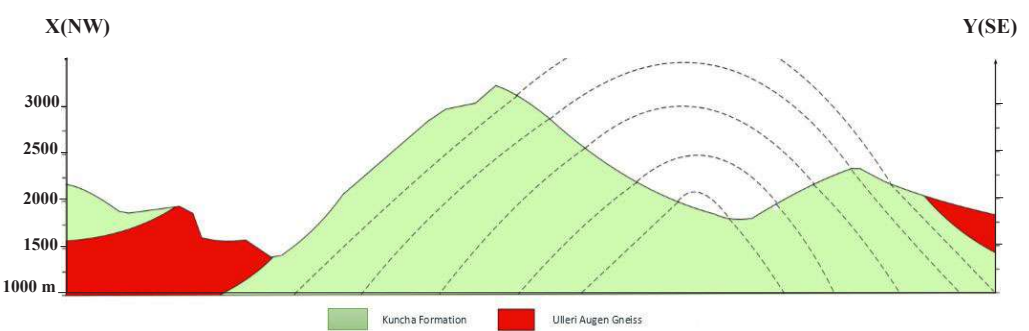

Fig. 3: Cross-section of the geological map of the study area: (a) Cross-section along A-B line from Fig. 2, and (b) Crosssection along X-Y line from Fig. 2.

porphyritic granitic textures are gradually developed. There is dominancy of porphyroclast of potash feldspar over other minerals as observed in outcrops.

\section{Composition and texture}

Some oriented samples were collected in the field for identification of the characteristics, deformational behavior and relationships of gneiss with country rocks. The microscopic study has been examined under the polarizing microscope. The major minerals are quartz, feldspar, muscovite, biotite, tourmaline, etc. Quartz grains exhibit subhedral to anhedral shape with intended contacts in most of the cases.

The sample of the Ulleri Augen Gneiss collected from the Chhalkhun Khola near Bhalche shows preferred orientation of minerals (Fig. 8). The mineral composition of gneiss is visually estimated as quartz: $40 \%$, plagioclase: $30 \%$, muscovite: $20 \%$ and other: $10 \%$. Grain size of different minerals varies from $0.85 \mathrm{~mm}$ to $0.05 \mathrm{~mm}$. Quartz grains are found polygonized.

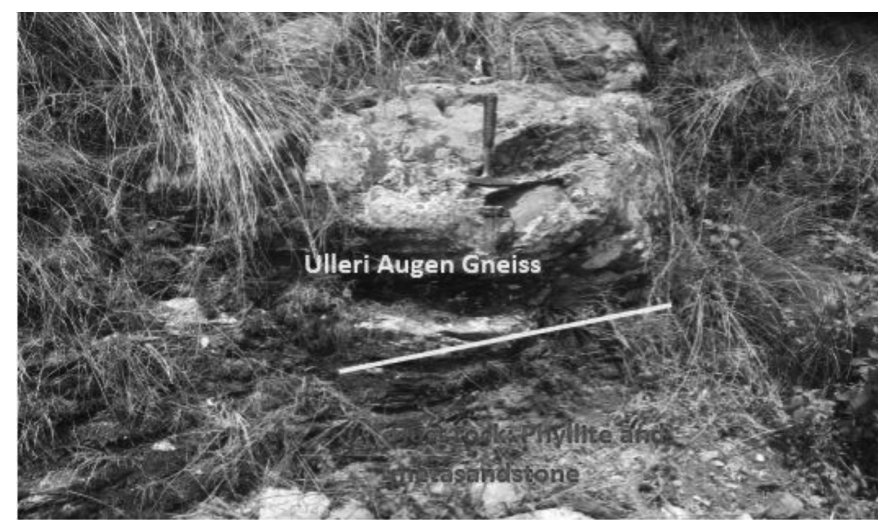

Fig. 4: Outcrop view of the Ulleri Augen Gneiss and the host rock of metasandstone showing interlayering beds at Bhalche area
The sample of schist collected from the outcrop of the road section along Dhunche to Syaprubesi near the Chileme Hydropower under thin section shows well preferred orientation of minerals along the major foliation with the mineral composition of quartz: $30 \%$, muscovite: $20 \%$, biotite: $20 \%$, plagioclase: $10 \%$ and garnet of $10 \%, \pm$ chlorite, respectively (Fig. 9). Garnet porphyroblast shows the inclusions of quartz aligned along the internal foliation which is across the direction of the major external foliation of the schist (Fig. 9) showing the evidence of poly-phase metamorphism.

Likewise, the sample of metasandstone (Fig. 10) belongs to the Kuncha Formation exposed near Bhalche area along the Bhalche-Nyuchet foot-trail. Under polarizing microscope quartz,

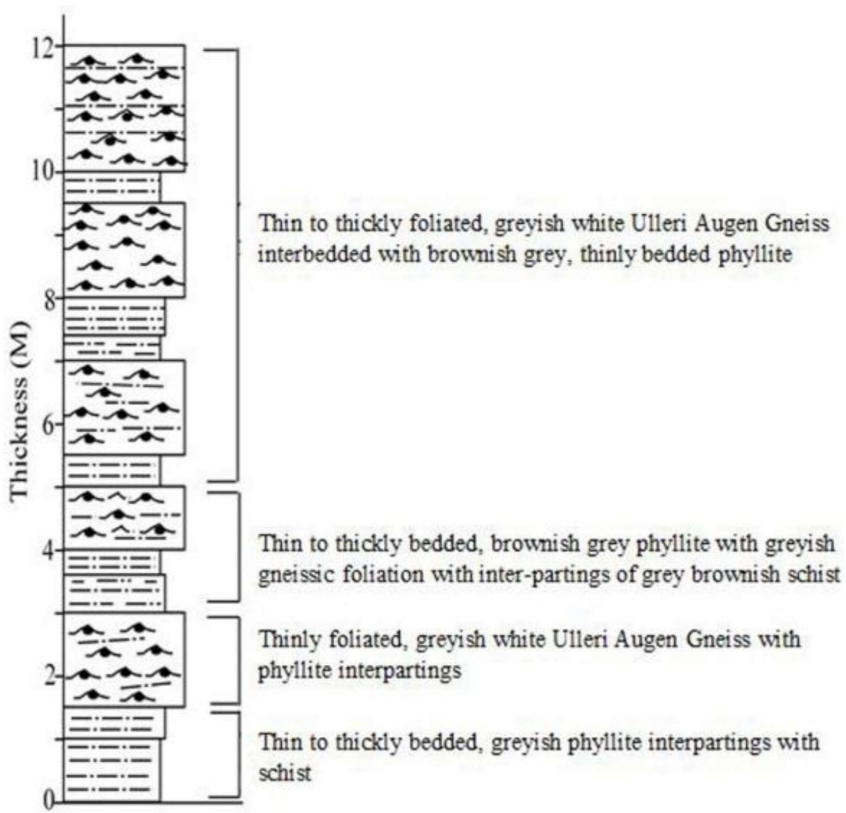

Fig. 5: Columnar section showing the contact relation of the Ulleri Augen Gneiss with the adjacent host at the right bank of Chhalkhun Khola near Bhalche area 


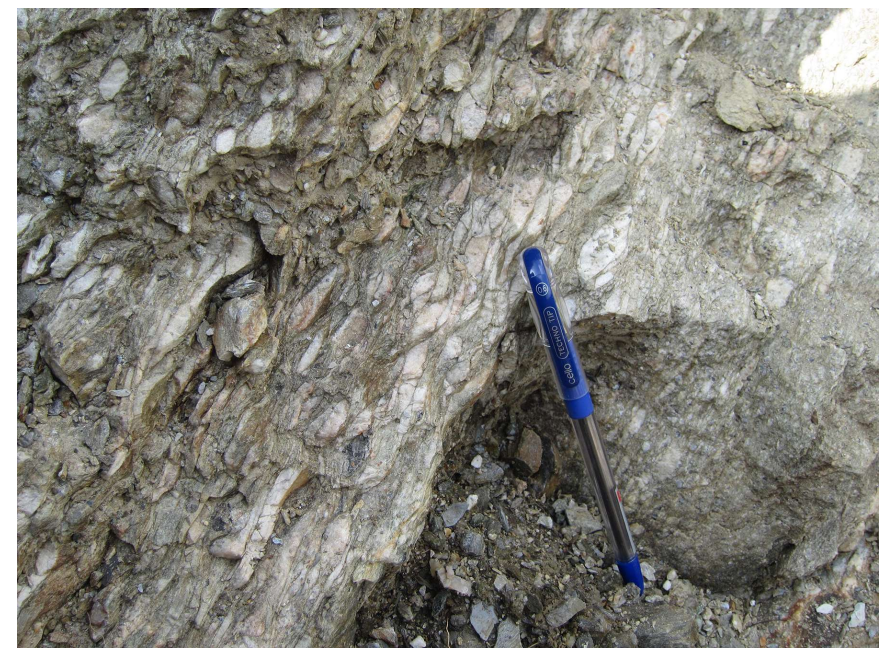

Fig. 6: Outcrop of the Ulleri Augen Gneiss along the KimtanGumbun road section showing interlayering of phyllite and the gneiss

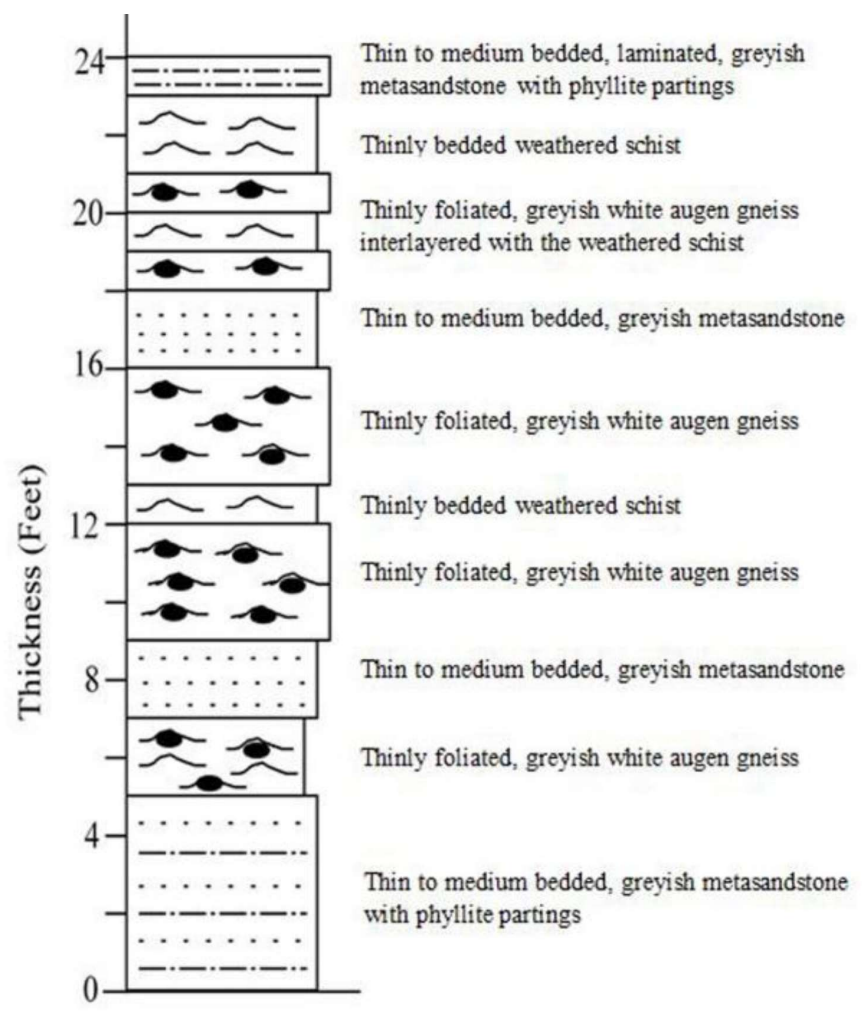

Fig. 7: Columnar section of the Ulleri Augen Gneiss observed at the Kimtan-Gombun road section showing the relation with country rocks.

feldspar, biotite, muscovite minerals are dominant minerals. The modal composition is quartz $65 \%$, muscovite $15 \%$ and feldspar $10 \%$, respectively. Quartz grain size is $0.10-20 \mathrm{~mm}$ and the undulose extinction is moderate. The quartz and feldspar are subhedral to anhedral in shape whereas biotite and muscovite minerals are elongated along the foliation plane.

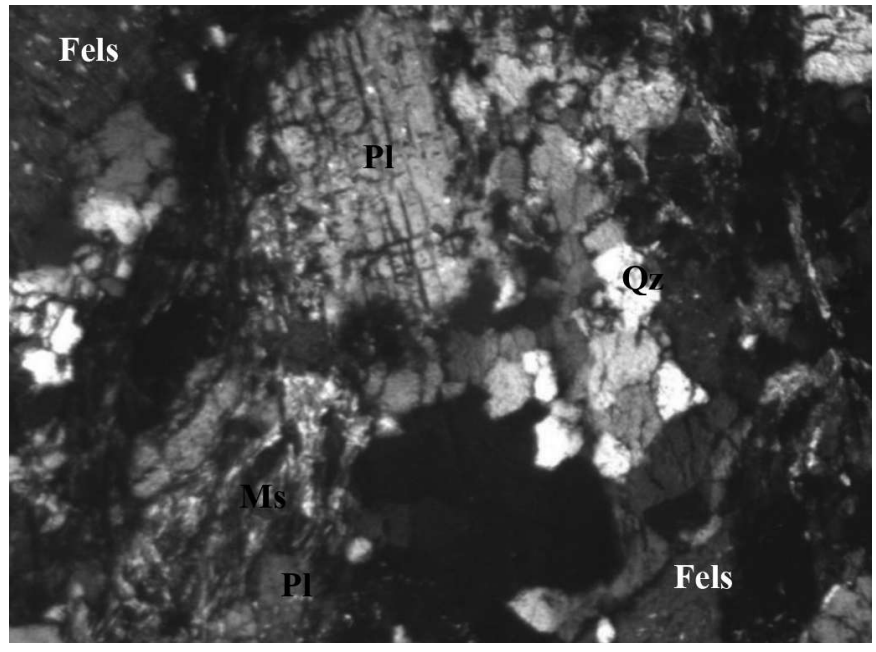

Fig. 8: Photomicrograph (UCN 4X) of gneiss showing polygonized crystals of quartz and feldspar. Fels: Feldspar, PI: Plagioclase, Qz: Quartz, Ms: Muscovite

\section{DEFORMATION AND METAMORPSHIM}

Rocks are highly deformed in the area. Deformation is indicated by the elongated grains of minerals as well as shear sense indicators. There is evidence of brittle shear zone as marked by mylonite with crushed and crumpled rock materials (Fig. 11). Several outcrop scale folds and faults were also observed in the region. The asymmetric augen shows the topto-south sense of shear in the area. In some outcrops the S-C fabric developed augen gneiss shows the top-to-the south sense of shearing (Fig. 12).

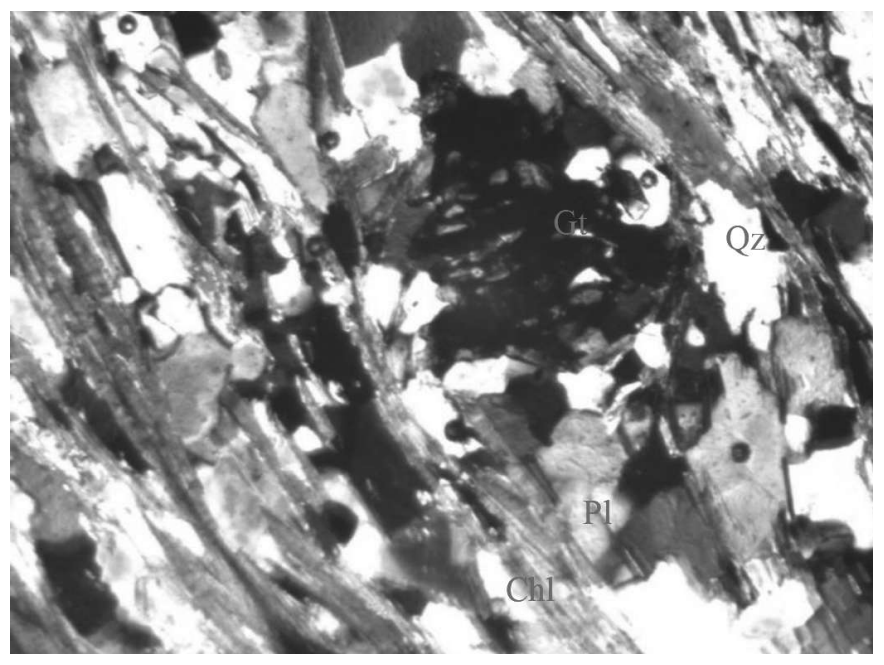

Fig. 9: Photomicrograph (UCN 4X) showing the garnet schist (sample taken from Syabrubesi area). Garnet has the inclusions of quartz with internal foliation. One set of foliation in schist is well-defined by the preferred orientation of micaceous minerals along the major external foliation. Quartz grains are in indented contact. Pl: Plagioclase, Qz: Quartz, Ms: Muscovite, Gt: Garnet, Chl: Chlorite 


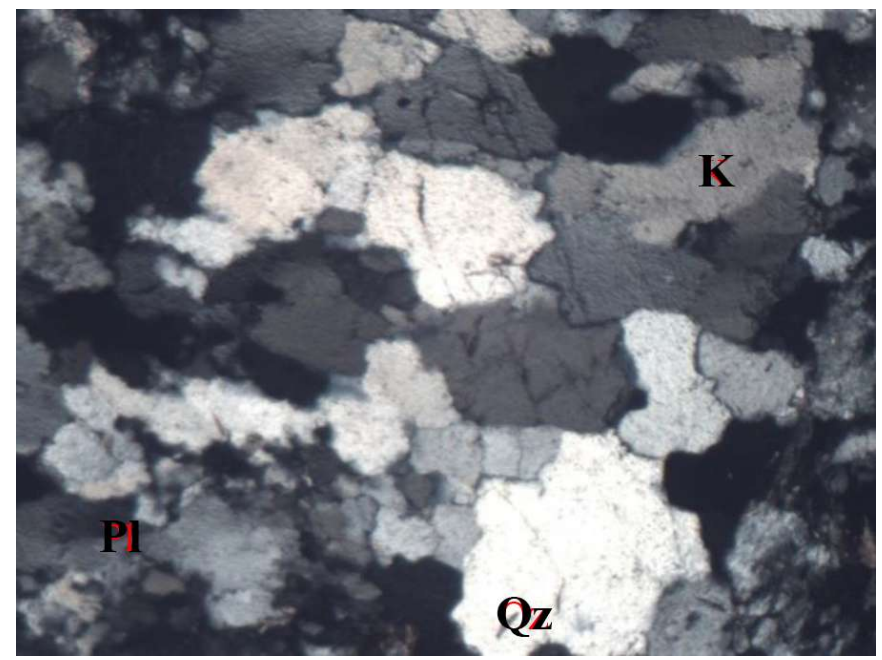

Fig. 10: Photomicrograph (UCN 4X) of metasandstone comprising the coarse-grained of quartz and feldspar. The grains are equigranular and the contact is irregular. $Q z$ : Quartz, PI: Plagioclase, K: K-Feldspar

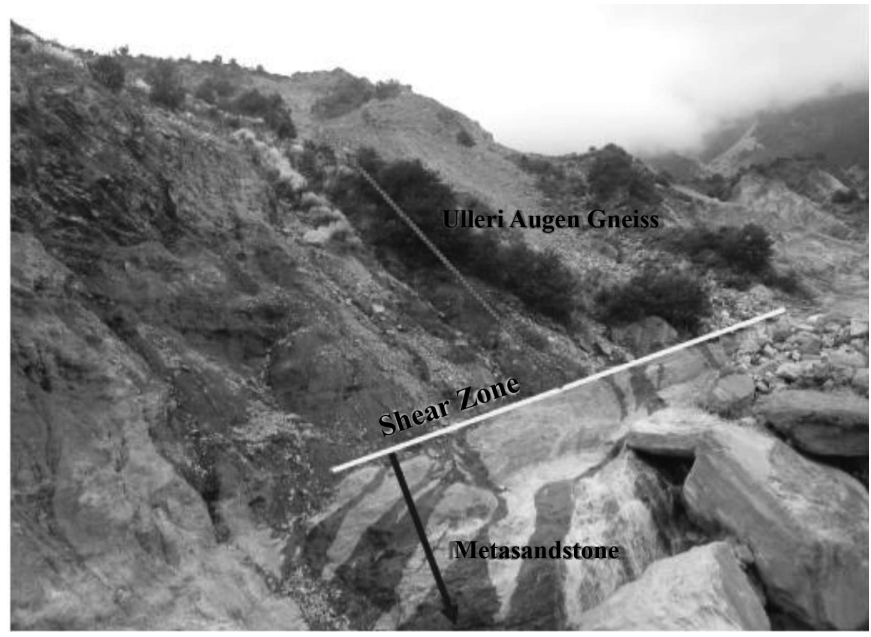

Fig. 11: The contact of Ulleri Augen Gneiss with metasandstone of country rock showing the shear zone at Jharlan-Chhyamthali area

Metamorphic events in study area are supported by the presence of metamorphic minerals such as chlorite, biotite and garnet, respectively. In the study area, the grade of metamorphism increases from south to north. In the southern part at BetrbatiDhaibun area, chlorite is found as a metamorphic index mineral and while moving to north biotite was observed in DhaibunDhunche and garnet was noted near the Syaprubesi area. It suggests that the study area possesses inverted gradient metamorphism (inverse metamorphism). In addition to this, the garnet at its rim shows the development of biotite and the formation of chlorite within the schist indicating the retrograde metamorphism. Garnet porphyroblast shows the inclusions of quartz aligned along the internal foliation which is across the

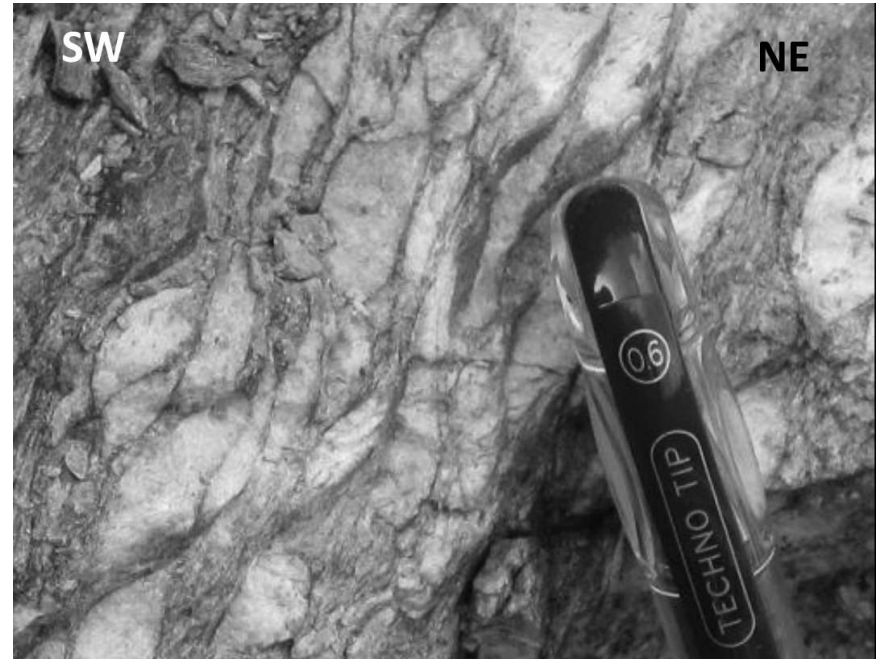

Fig. 12: An outcrop of the Ulleri Augen Gneiss showing augen shaped porphyroclasts of $\mathrm{K}$-feldspar and S-C texture showing top to the south sense of shear

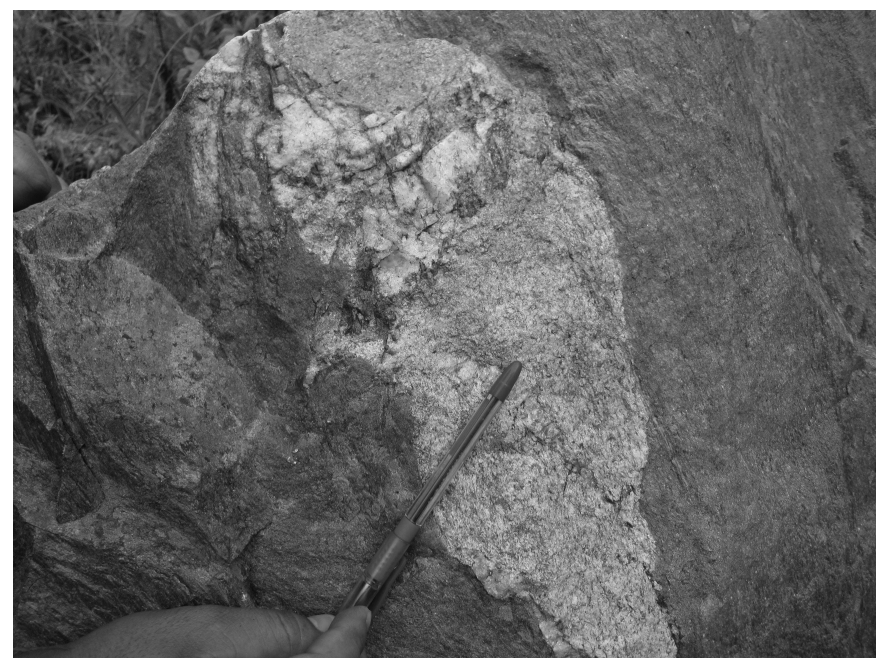

Fig. 13: Outcrop view of banded gneiss showing contact relations with the host rock

direction of the major external foliation of the schist (Fig. 9) showing the evidence of poly-phase metamorphism.

Metamorphism along with deformation of the bandings of minerals show curve path of alignment was observed in the outcrop of gneiss in the Chyamthali area near the Jharlan pairo (Fig. 13).

\section{DISCUSSIONS}

The study area comprises vast lithological distribution of the Kuncha Formation. According to the DMG, the study area lies in the Ranimatta Formation which comprises of mediumgrained, thin-to thick-bedded greyish black metasandstone, 
psammatic phyllite and thick outcrop of well banded orthogneiss. The Ulleri Augen Gneiss is one of the major lithological distributions in the study area. It is extended laterally from the Khodku-Siruchet area in the eastern part of Rasuwa to the Jharlan-Chhyamthali area in the western part of the Nuwakot and the Dhading Districts. The Ulleri Augen Gneiss is felsic augen gneiss that was intruded in the Kuncha Formation. The augen gneiss consists of plagioclase as the larger grain and surrounded by the biotite and muscovite as the matrix revealing the perfect eye shape (augen structure). Banded gneiss consists of alternating bands of light and darker minerals. Quartz-grain microstructures show that the grain boundaries are tangential to sutures. However, the majority of the quartz grain show indented contact. It can also be explained as the pressure solution phenomenon. The maximum stress direction is indicated by north-south representing the present trend of the Himalayan collision.

There could be numerous geological and tectonic phenomenon involved in the formation of the Ulleri Augen Gneiss. Initially, the granitic material emplaced within the Kuncha Formation and solidified as felsic pluton for millions of years. The coarse-grained texture obtained in the field sample is the result of gradual cooling of the felsic magmatic materials. Due to several tectonic activities, the plutonic rock passed through many stages of metamorphism and deformation forming augen gneiss showing gneissic texture. The minerals present are potash-feldspar, quartz, biotite, muscovite and plagioclase. The country rock comprises the vast intermixed combination of monotonous succession of greenish grey medium to coarsegrained metasandstone and medium to fine grained, greenish psammatic phyllite. The emplacement of the granite intrusion has greater impact in the adjacent rocks. The most remarkable note is the field relation. Both the concordant and discordant relations were found in the present study. It shows the complex genesis of the magmatic pluton. In some places, the country rocks are assimilated. This can be seen in the field by observing xenoliths of host rocks. Eventually, the degree of grain size and minerals get pro-graded. The Ulleri Augen Gneiss can be correlated with the different augen gneiss distributed in the Nepal Himalaya. It can be correlated with the Melung Salleri Augen Gneiss or Phaplu Augen Gneiss of eastern Nepal whereas similar type of augen gneiss has been mapped in the Chainpur area of Far-Western Nepal.

Precise age determination by U-Pb dating of zircons from the Ulleri gneiss has been difficult because of the presence of zircon rims less than 10 micron meter in thickness inherited cores and multiple intrusive events (Celerier et al., 2009; Kohn et al., 2010; Martin et al., 2011), dating the type location of the Ulleri Augen Gneiss and compiling the results from previous studies, determined that the Ulleri Augen Gneiss was crystallized at $1780 \pm 29 \mathrm{Ma}$ an earlier lithologically similar felsic intrusion into the Kuncha Formation was dated at $1878 \pm 22 \mathrm{Ma}$. On the other hand, Le Fort and Rai (1999) obtained an age of $1.74 \mathrm{Ga}$ by dating $\mathrm{Rb}-\mathrm{Sr}$ isotopes for the Ulleri Augen Gneiss of west Nepal.

\section{CONCLUSIONS}

- The rock succession exposed in Ramche-Chhyamthali area can be mapped under a single geological unit as the Kuncha Formation with a prominent member of Ulleri Augen gneissic succession within it.

- From lithological and textural view point, the Ulleri Augen Gneiss appears in various forms like augen, banded, layered and sometimes more granitic, etc. in the region. There is great variation of mineral composition as well as fabric of the rock along the strike.

- The gneissic zone is highly influenced by tectonic events. Several inter-fingering of granitic veins or sills in some places make the host body very much altered. Both concordant and discordant relationship of gneiss with the host rocks is observed. In the eastern region the gneiss shows concordant relationship whereas in the western part it shows discordant relationship with the host rocks.

The rocks of the region are highly deformed, sheared and metamorphosed. Shear sense indicators like asymmetric augen of quartz and feldspar and $\mathrm{S}-\mathrm{C}$ fabric developed in the rocks show top-to-the south sense of shearing in the rocks. It can ultimately be linked with the movement of the Higher Himalayan crystalline rocks through the MCT over these Lesser Himalayan rocks.

The grade of the metamorphism from southern to northern region of the study area is gradually increased from chlorite to garnet isograds approaching the MCT as the evidence of the inverted gradient. Retrograde metamorphism was recorded by the presence of biotite at the rims of garnet and the presence of the chlorite in the schist of the Kuncha Formation. The area is affected by poly-phase metamorphism. The adjacent rocks get assimilated and suffer from contact and regional metamorphism. The host rocks adjacent to gneissic body sometimes show pseudo-gneissic texture. Quartz-grain microstructures like the indented to suture contact among the grains indicates higher influence of temperature and pressure in the rocks.

Based on the field relation and texture analysis, the evolution of the protolith of this Ulleri Augun Gneiss can be interpreted as a multi-story emplacement within the host rocks during and immediately after the sedimentation.

\section{ACKNOWLEDGEMENTS}

We are grateful to Prof. Dr. Ram Bahadur Sah for his valuable suggestions throughout the study period. Our sincere gratitude goes to Prof. Dr. Lalu paudel for his support. We are immensely thankful to Amit Neupane, Sudarshon Sapkota, Harish Dangi and Gunanidhi Pokhrel (geologists) for their valuable help and suggestions in GIS analysis. Sincere thanks are extended to Depak Gautam, Purushottam Neupane, Ashis K.C., Kamal Kafle, Balram Bhandari, Lokmani Oli, Sanjeew 
Bhujel and Bhupendra K.C. for their continuous support and valuable suggestions.

\section{REFERENCES}

Arita, K., 1983, Origin of the inverted metamorphism of the Lower Himalayas, central Nepal. Tectonophysics, v. 95, pp. 43-60. https://doi.org/10.1016/0040-1951(83)90258-5

Celerier, J., Harrison, T.M., Yin A., and Webb, A.A.G., 2009, The Kumaun and Garhwal Lesser Himalaya, India. Part 1: Structure and stratigraphy; Geological Society of America Bulletin, v. 121 (9/10), pp. 1262-1280. https://doi.org/10.1130/B26344.1

Colchen, M., Le Fort, P., and $\mathrm{Pe}^{\wedge}$ cher, A., 1980, Carte geologique Annapurna-Manaslu-Ganesh, Himalaya du Nepal, Nepal central. Edition du Centre Natl. Rech. Sci., Paris Echelle $1: 200000$.

Colchen, M., Le Fort, P., and $\mathrm{Pe}^{\wedge}$ cher, A., 1986, Recherches geìologiques dans I'Himalaya du Neìpal. Annapurna, Manaslu, Ganesh. Eìdition du CNRS, 136 p.

Gansser, A., 1964, Geology of the Himalayas. Interscience Publisher, London, 289 p.

Kohn, M.J., Paul, S.K., and Corrie, S.L., 2010, The lower Lesser Himalayan sequence: A Paleoproterozoic arc on the northern margin of the Indian plate, Geological Society of America Bulletin, v. 122(3-4), pp. 323-335, doi:10.1130/B26587.1.113. https://doi.org/10.1130/B26587.1

Le Fort, P. and $\mathrm{Pe}^{\wedge}$ cher, A., 1974, Les gneiss oeilleìs du Moyen Pays neìpalais: un ensemble volcano-seìdimentaire acide $\mathrm{d}^{\prime} \mathrm{a}^{\wedge}$ ge paleìozoi" que ou plus ancien en Himalaya. Compte Rendu Acad. Sci. Paris, 278, pp. 3283-3286.

Le Fort, P., 1975a, Himalaya: the collided range. Present knowledge of the continental arc. American Journal of Science, v. 275A, pp. 1-47.

Le Fort, P., 1975b, Les formations cristallophyliennes de la "Dalle du Tibet" en Marsyandi. In: Bordet, P. (Ed.), Recherches geìologiques dans I'Himalaya du Neìpal, reìgion du Nyi-Shang. Ed. Cent. Natl. Rech. Sci., Paris, pp. $21-47$.

Le Fort, P. and Rai, S.M., 1999, Pre-Tertiary felsic magmatism of the Nepal Himalaya: recycling of continental crust. Journal of Asian Earth Sciences, v. 17, pp. 607-628. https://doi.org/10.1016/S 1367-9120(99)00015-2

Martin, A.J., Burgy, K.D., Kaufman, A.J., and Gehrels, G.E., 2011, Stratigraphic and tectonic implications of field and isotopic constraints on depositional ages of Proterozoic Lesser Himalayan rocks in central Nepal. Precambrian Research, v. 185 (1-2), pp. 1-17. doi:10.1016/j.precamres.2010.11.003

Parrish, R.R. and Hodges, K.V., 1996, Isotopic constraints on the age and provenance of the Lesser and Greater Himalayan sequences, Nepalese Himalaya. Geological Society of American Bulletin, v. 108, pp. 904-911. h t t p s : / / d o i.org/10.1130/00016 7606(1996)108<0904:ICOTAA > 2.3.CO;2

$\mathrm{Pe}^{\wedge}$ cher, A. and Le Fort, P., 1977, Origin and Significance of the Lesser Himalaya augen gneisses. In: Jest, C. (Ed.), Ecologie et geologie de I'Himalaya, Coll. Int. vol. 268. CNRS, Paris, pp. 319-329.

$\mathrm{Pe}^{\wedge}$ cher, A., 1978, Deìformation et meìtamorphisme associeìs aì une zone de cisaillement. Example du grand chevauchement central Himalayen (M.C.T.), transversal des Annapurna et du Manaslu, Nepal. Theìse de doct. d'Eitat, Univ. de Grenoble, France, 354 p.

Rai, S.M., 1998, Les nappes de Katmandou et du Gosainkund, Himalaya du Népal central (Etude cartographique, structural, métamorphisme, géochimique et radiochronologique). Ph. D. Thesis, Univerité Joseph Fourier, Grenoble I, France, 244 p.

Rai, S.M., Upreti, B N., and Yoshida, M., 2008, Report on Geological Field Survey of Langtang area, central Nepal. Submitted to National Park and Wildlife Conservation Department, Government of Nepal, Babar Mahal, Kathmandu, Nepal. 16 p (Unpublished).

Rai, S.M., Yoshida, M., Upreti, B. N., Ulak, P.D. and Bhattarai, T.N., 2017, Geology of the Lesser Himalayan sequences along the Bhotekoshi River section between Syabru Besi and Rasuwa Gadhi (Nepal-China boarder) area, central Nepal Himalaya. Bulletin of Nepal Geological Society, v. 34, pp. 65-74.

Stöcklin, J. and Bhattrai, K.D., 1977, Geology of Kathmandu area and central Mahabharat range Nepal. In: Himalaya Report, Department of Mines and Geology, Kathmandu, Nepal, 86 p.

Stöcklin, J., 1980, Geology of Nepal in its regional frame. Journal of Geological Society, London, v. 137, pp. 1-34 https://doi.org/10.1144/gsjgs.137.1.0001

Tater, J.M., Shrestha, S.B., and Shrestha, J.N., 1983, Geological map of western Nepal at 1:250000 scale. Department of Mines and Geology (DMG), Kathmandu, Nepal.

Upreti, B.N. and Le Fort, P., 1999, Lesser Himalayan crystalline nappes of Nepal: problem of their origin. In: Macfarlane, A., Quade, J., Sorkhabi, R. (Eds.), Geological Society of America, Special Paper, v. 328, pp. 225-238. https://doi.org/10.1130/0-8137-2328-0.225 